\title{
Perilaku Titanium Murni (CPTi grade 2) terhadap Lapisan Hydroxyapatite Untuk Aplikasi Medis
}

\author{
Desmarita Leni. ${ }^{1}$, Gunawarman ${ }^{2}$, Yuli Yetri ${ }^{3}$, Jon Affi ${ }^{4}$ \\ Penulis ${ }^{1}$, Pembimbing ${ }^{2,3,4}$ \\ Alamat Cengkeh no 2 lubeg, Padang.Indonesia ${ }^{1}$ \\ Email: desmaritaleni@gmail.com
}

\begin{abstract}
Abstrack:Penelitian ini membahas perilaku titanium murni (CPTi) dalam larutan Hydroxyapatite(HA) buatan untuk aplikasi medis. Ada tujuh benda uji titanium murni yang digunakan dalam pengujian ini. Commercial Pure Titanium (CpTi). Spesimen dibersihkan dan dilakukan pelapisan dengan HA dengan metode EPD. Pengujian dilakukan dalam tujuh variasi waktu; 5 menit, 10 menit, 15 menit, 20 menit, 25 menit, 30 menit dan 35 menit. Pengujian ini melihat tingkat lapisan HA terhadap CPTi apakah bisa menyatu dengan metode EPD. Hasil pengujian ini berguna untuk referensi pasien dan dokter implan tulang, dan implan gigi dalam memilih bahan material ortodontik yang lebih baik. Hasil penelitian menunjukkan CPTi memiliki tingkat pelapisan yang baik seperti variasi ketebalan HA yang didapat $24,8 \mu \mathrm{m}(5$ menit) sampai dengan ketebalan HA 32,7 $\mu$ m (35 menit)
\end{abstract}

\section{PENDAHULUAN}

Dunia material saat ini berkembang dengan sangat pesat, salah satu aplikasinya adalah bidang biomaterial. Biomaterial yang ideal adalah bahan atau material yang memiliki biokompatibilitas yang baik, sifat mekanik yang baik dan proses manufaktur yang mudah [1]. Bahasan menarik dalam hal biomaterial adalah implantasi. Implan digunakan dengan berbagai alasan antara lain adalah mengganti jaringan rusak yang disebabkan oleh penyakit maupun trauma, sebagai filler dan support fase penyembuhan.

Secara terminologi umum biokompatibilitas menjelaskan kondisi dimana tidak terjadi interaksi berbahaya antara material asing dengan tubuh. Biokonpatibilitas merupakan sistem yang mencakup fisik, kimia, biologis, medik dan aspek desain [2]. Ductility, thoughness, creep dan wear resistance adalah sifat mekanik yang diperlukan untuk biomaterial, sedangkan metode fabrikasi, konsistensi, tingkat kenyamanan dan biaya produksi adalah karakter manufaktur yang pada akhirnya menentukan pemilihan penggunaan bahan implan [1].

Salah satu jenis bahan implan logam yang sering digunakan adalah Titanium. Hal ini dikarenakan titanium mampu memenuhi persyaratan sebagai bahan implan. Titanium yang digunakan sebagai implan dapat berupa logam titanium murni maupun logam paduan titanium. Logam titanium murni dan paduan titanium memiliki biokompatibilitas dan biomekanis yang lebih baik dari logam lain [3]. Titanium mempunyai kemampuan melekat ke tulang yang disebut osseointegration. Pada osseointegration, tulang berkontak langsung dengan permukaan implant sehingga terjadi pertumbuhan tulang disekitar implan. Secara biologi titanium memiliki sifart inert dan memiliki ketahanan korosi yang cukup tinggi dan dapat spontan membentuk lapisan $\mathrm{TiO}_{2}$ (Titanium Oksida) di permukaannya. Bahan yang memiliki biokompatibilitas belum tentu memiliki sifat bioaktif. Suatu bahan dikatakan bioaktif jika tidak hanya memberikan osteoconductive tapi juga mampu memberikan osteoinductive.

Karakteristik titanium adalah Unalloyed Comercial Pure (CP) titanium yang tersedia empat kelas yang berbeda, 1, 2, 3 dan 4, yang digunakan berdasarkan ketahanan korosi. Titanium grade 2 lebih kuat dari grade 1 dan tahan korosi sangat baik, kemampuan dan kekuatan superior antara nilai 1 dan 3. Ini adalah kelas yang banyak digunakan yang menawarkan kekuatan hasil minimal $275 \mathrm{MPa}$ (40ksi). Titanium (CPTi grade 2) untuk aplikasi medis sering digunakan seperti bahan implan tulang, gigi, pelapisan permukaan (surface coating), dan pada saat ini di pakai pula untuk bahan mahkota tiruan, gigi tiruan 
sebagian, gigi tiruan penuh dan untuk bahan wire kawat orthodontic.

\section{TINJAUAN PUSTAKA}

Titanium merupakan material nonmagnetic. Titanium juga dapat menghantarkan panas dengan sangat baik. Koefisien termal untuk jenis material titanium lebih rendah dari baja. Material ini juga mempunyai sifat tahan korosi yang sangat baik [7]. Titanium ini juga bayak digunakan untuk peralatan militer. Oleh karena kekuatannya, unsur ini digunakan untuk membuat peralatan perang (tank) dan untuk membuat pesawat ruang angkasa dan untuk alat kedokteran seperti bahan implan gigi, penyambung tulang, pengganti tulang tengkorak, struktur penahan katup jantung.

Pemanfaatan titanium dalam aplikasi biomedis didasarkan pada beberapa keunggulan karakteristik mekanisnya, yaitu:

1. Kekuatan titanium setara dengan baja, namun lebih ringan sekitar $60 \%$ dari baja.

2. Kekuatan lelah (fatigue strength) yang lebih tinggi daripada paduan aluminium.

3. Tahan terhadap suhu tinggi. Pemaparan dengan temperatur diatas $150^{\circ} \mathrm{C}$ mengakibatkan aluminium kehilangan kekuatannya, namun dapat memberikan ketahanan pada aluminium pada titanium alloy.

4. Ketahanan korosi titanium lebih tinggi dibandingkan dengan aluminium dan baja.

5. Rasio berat-kekuatan yang lebih rendah daripada aluminium. Hal ini mengakibatkan komponen-komponen yang terbuat dari titanium membutuhkan ruang yang lebih sedikit dibanding aluminium.

6. Absorbsi titanium pada saluran pencernaan makanan yang rendah. Logam titanium yang digunakan sebagai implan dapat diterima sangat baik oleh jaringan tubuh karena biokompatibilitasnya [8].

Sifat Mekanik Titanium CPTi Grade 2

Titanium (Ti) telah menjadi material pilihan untuk banyak digunakan dalam implantasi gigi dan bedah tulang. Hal tersebut dikarenakan minimalnya reaksi jaringan yang diakibatkan oleh penanaman material ini dalam tubuh. Pada penanaman material ini terjadi reaksi biologis secara alami yaitu terbentuknya jaringan baru yang kemudian melekat pada lapisan oksida pada permukaan titanium. Titanium (CPTi grade 2) merupakan material allotropik dengan dua bentuk kristalografi yaitu alpha $(\alpha)$ yang mempunyai bentuk hexagonal close packed (HCP) pada temperatur $<882,5^{\circ} \mathrm{C}$ dan beta ( $\beta$ ) yang mempunyai bentuk body centered cubic (BCC) pada temperatur > $882,5^{\circ} \mathrm{C}$.

Tabel.2Sifat Mekanik Beberapa Jenis

Titanium

\begin{tabular}{|l|l|l|l|l|}
\hline $\begin{array}{l}\text { Sifat } \\
\text { Mekanik }\end{array}$ & $\begin{array}{c}\text { Gra } \\
\text { de 1 }\end{array}$ & $\begin{array}{c}\text { Grade } \\
\text { 2 }\end{array}$ & $\begin{array}{c}\text { Grad } \\
\text { e 3 }\end{array}$ & $\begin{array}{c}\text { Grad } \\
\text { e 4 }\end{array}$ \\
\hline $\begin{array}{l}\text { Tensile } \\
\text { Strenght } \\
\text { (Mpa) }\end{array}$ & 240 & 345 & 450 & 550 \\
\hline $\begin{array}{l}\text { Yield } \\
\text { Strength } \\
\text { (Mpa) }\end{array}$ & 170 & 275 & 380 & 485 \\
\hline $\begin{array}{l}\text { Elongation } \\
\text { (\%) }\end{array}$ & 24 & 20 & 18 & 15 \\
\hline $\begin{array}{l}\text { Reduction } \\
\text { of Area } \\
\text { (\%) }\end{array}$ & 30 & 30 & 30 & 25 \\
\hline $\begin{array}{l}\text { Modulus } \\
\text { of } \\
\text { Elasticity } \\
\text { (Gpa) }\end{array}$ & 102 & 102 & 103 & 104 \\
\hline $\begin{array}{l}\text { Poison } \\
\text { ratio }\end{array}$ & 0,34 & 0,34 & 0,34 & 0,34 \\
\hline $\begin{array}{l}\text { Condition } \\
\text { Ann } \\
\text { eale } \\
\text { d }\end{array}$ & $\begin{array}{c}\text { Annea } \\
\text { led }\end{array}$ & $\begin{array}{l}\text { Anne } \\
\text { aled }\end{array}$ & $\begin{array}{c}\text { Anne } \\
\text { aled }\end{array}$ \\
\hline (Wt \%) Ti & 99,5 & 99,2 & 99,1 & 99,0 \\
\hline
\end{tabular}

Penggunaan titanium sebagai implan didasarkan pada densitas yang rendah, ketahanan korosi yang sempurna, modulus mekanikal yang cocok dengan tulang bila dibanding dengan material lain. Berdasarkan jumlah oksigen yang terkandung maka Commercial Pure Titanium dikasifikasikan menjadi 4 grade mulai dari grade 4 dengan kandungan oksigen maksimal $0.4 \%$ dan grade 1 minimal $0.18 \%$. Karena biokompatibilitas dan karakteristik fisik yang maksimal ini maka Titanium murni (CPTi grade 2) maupun Titanium paduan banyak 
digunakan pada bidang medis dengan variasi yang beragam mulai dari sambungan tulang, pengganti tulang, implan dental, pembuluh jantung buatan, dll. Dengan adanya lapisan tipis dalam ukuran $\mathrm{nm}$ membuat titanium menjadi material yang sangat terlindung dari korosi. Dengan minimalisnya peluruhan ion sebagai hasil residu pada jaringan tubuh sehingga material ini dapat diklasifikasikan sebagai material inert atau secara elektrokimia merupakan material yang pasif pada semua kombinasi potensial dan $\mathrm{pH}$.

\section{Hydroxyapatite (HA)}

Hydroxyapatite (HA) dengan rumus kimia $\mathrm{Ca}_{10}\left(\mathrm{PO}_{4}\right)_{6}(\mathrm{OH})_{2}$ sering dikenal sebagai calcium phosphate tribasic. Selama hampir 2 dekade ini banyak mendapat perhatian di dunia biomaterial sebagai material implan dikarenakan sifat bikompabilitasnya yang sangat baik. HA juga merupakan merupakan material yang bersifat bioaktif disbabkan karena rasio kalsium-fosfat pada material ini mirip dengan tulang dan gigi alami [9].

Keunggulan dari HA adalah kemiripannya dengan struktur kimia tulang dan jaringan keras pada mamalia. Material ini dapat mendorong pertumbuhan tulang baru, serta mempercepat proses penyatuan tulang. Untuk memenuhi syarat sebagai material substitusi tulang, HA harus didesain dalam bentuk komposit dengan polimer, karena tulang merupakan komposit alami yang terdiri dari bahan organik dan inorganik. Kitosan merupakan salah satu polimer yang dapat digunakan sebagai komposit. Ha-kitosan karena memiliki sifat spesifik, yaitu tidak beracun, osteokonduktif, biocompatible, biodegradable, dan tidak carcinogen.

\section{METODOLOGI}

Elektroforesis Deposisi (EPD) merupakan suatu teknik yang menggunakan mekanisme elektroforesis untuk menggerakkan partikel bermuatan dalam larutan atau suspensi karena adanya pengaruh medan listrik, sehingga partikel tersebut akan mengendap pada permukaan suatu substrat dan membentuk lapisan tipis dengan ketebalan tertentu [15]. Metode EPD dapat digunakan untuk melapiskan material logam yang bertujuan diantaranya meningkatkan biokompatibilitas dari logam sehingga aman digunakan di dalam tubuh makhluk hidup [16].

EPD biasanya dilakukan menggunakan dua elektrode sel yaitu katode (elektrode negatif) dan anode (elektrode positif). Mekanisme EPD terdiri atas dua tahap, yaitu tahap pertama, migrasi partikel bermuatan di dalam suspensi karena adanya gaya tarik dari penggunaan medan listrik, kemudian aliran listrik antara dua elektrode positif dan negatif menyebabkan partikel $\mathrm{Ha}$ akan bergerak ke arah yang berlawanan dengan muatannya [17]. Tahap kedua merupakan tahap pengendapan, koagulasi partikel membentuk lapisan pada katode (tahap deposisi). Pada tahap ini partikel HA akan terdeposisi pada permukaan logam yang bertindak sebagai elektrode, kemudian akan menutup rapat permukaan logam secara homogen dalam bentuk lapisan film. Lapisan ini sebagai hasil deposisi partikel HA yang menempel pada logam. Ilustrasi pergerakan partikel pada proses EPD dapat dilihat pada Gambar berikut:

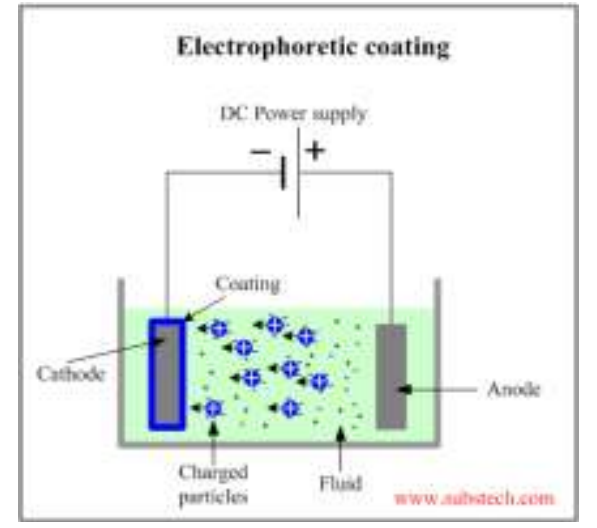

Gambar. Pelapisan dengan Metode Electrophoretic Deposition[17]

\section{Bahan Penelitian}

Bahan yang diperlukan dalam penelitian ini adalah serbuk Hydroxyapatite (HA) dan sheet Titanium murni (CPTi), asam nitrat, amplas kasar, halus dan metanol.

\section{Alat Penelitian}

Alat yang digunakan dalam penelitian ini terdiri dari EPD sebagai alat pelapisan, gelas beker, lem untuk perekat material, mikroskop stereo Olympus SZX10, sintering 
merek Nabertherm heat $30-3000^{\circ} \mathrm{C}, \mathrm{PH}$ meter, stop watch dan pengamatan karakteristik dengan SEM Hitachi S-3400 N dan pengukuran ketebalan pada CPTi yang terlapisi HA dengan Thickness Gauge series GM 280.

\section{Penyiapan Sampel}

Pada tahapan ini sampel berupa material titanium murni (CPTi grade 2) dipotong sesuai standar pengujian ukuran $10 \mathrm{~mm} \times 10$ $\mathrm{mm}$. Sampel yang telah dipotong lalu dihaluskan permukaannya menggunakan amplas. Amplas yang digunakan merupakan amplas dengan kekasaran mesh 400, 800, 1200, 1500, dan 2000. Amplas tersebut digunakan secara berurutan dari kekasaran mesh kecil, sampai permukaan dari sampel harus dan bebas dari goresan (mengkilap).

\section{Pelapisan dengan Menggunakan Metode} Electrophoretic Deposition (EPD)

Pelapisan CPTi dengan HA digunakan metode Electrophoretic Deposition dengan melakukan pencampuran HA dan ethanol dengan perbandingan $75 \mathrm{ml}$ ethanol dan 1.85 gr HA sehingga membentuk larutan HA dengan $\mathrm{PH}$ 4,6 $\mathrm{PH}$ normal larutan yang digunakan untuk metode Elctrophoretic Deposition adalah PH 4 oleh karena itu dilakukan penambahan Asam Nitrat $\left(\mathrm{HNO}_{3}\right)$.

Untuk persiapan instrumen alat yang digunakan seperti kawat tembaga untuk melilit benda uji sewaktu pelapisan berlangsung. 2 buah kawat tembaga, 2 buah jumper, grafit, dan satu set digital power supply. Grafit disini bertindak sebagai anoda dan sampel CPTi sebagai katoda. Setelah sampel kering, kawat tembaga pertama di tempelkan pada benda uji dengan menggunakan kawat yang dililit, dan yang kedua dililitkan pada grafit. Masing-masing kawat tembaga di jepit dengan jumper, dimana grafit sebagai anoda dihubungkan dengan arus positif dan sampel sebagai katoda dihubungkan dengan arus negatif ditunjukkan pada Gambar berikut:

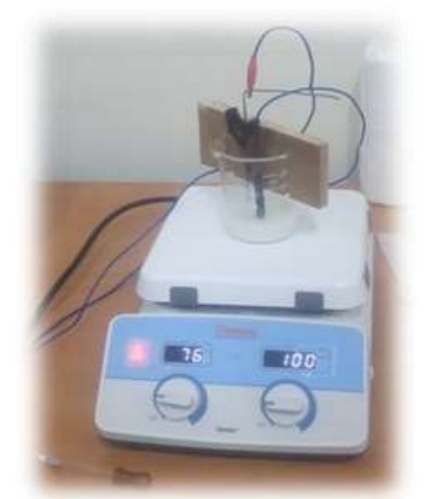

Gambar. Instrumen peralatan EPD Pengujian dilakukan dengan 7 varisi waktu dan 7 buah benda uji, voltase yang digunakan 40 volt seperti yang terdapat pada Tabel berikut :

Tabel Variasi waktu pada benda uji CPTi

\begin{tabular}{|c|c|c|}
\hline No & $\begin{array}{c}\text { Waktu } \\
\text { (Menit) }\end{array}$ & Voltase (Volt) \\
\hline 1 & 5 & 40 \\
\hline 2 & 10 & 40 \\
\hline 3 & 15 & 40 \\
\hline 4 & 20 & 40 \\
\hline 5 & 25 & 40 \\
\hline 6 & 30 & 40 \\
\hline 7 & 35 & 40 \\
\hline
\end{tabular}

\section{Proses Sintering}

Masing-masing sampel yang telah terlapisi, masih sangat rapuh dan lapisannya mudah terlepas. Oleh karena itu dilakukan proses sintering atau pemanasan. Proses ini bertujuan untuk meningkatkan bonding antara HA dengan CPTi agar menjadi kuat dan tidak mudah terlepas. Proses sintering ini menggunakan High Temperature tungku terbuka Nobertherm $30-3000^{\circ} \mathrm{C}$ terlihat pada Gambar. Pada saat proses sintering tempratur yang digunakan $700^{\circ} \mathrm{C}$.

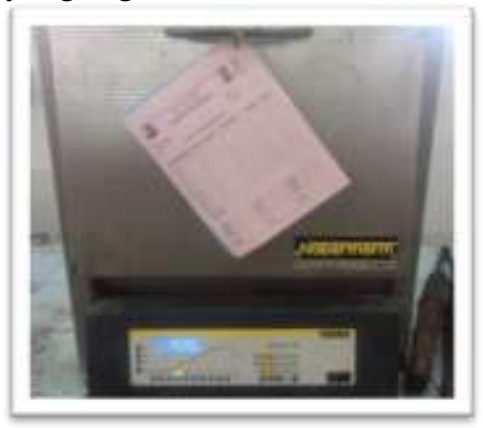

Gambar 3.3 Tungku terbukaTube Furnace Nobertherm $30-3000^{\circ} \mathrm{C}$ 
Proses ini terdiri dari pemanasan (Heating), Penahanan temperatur (Holding) agar terjadi pemerataan temperatur pada sampel, dan pendinginan di dalam tungku (Anealling).

\section{Pengamatan dengan Mikrokop Optik}

CPTi yang telah terlapisi HA akan diamati permukaanya dibawah mikroskop stereo Olympus SZX10. Hal ini bertujuan untuk mengamati hasil lapisan merata atau tidak dan apakah seluruh permukaan sampel terlapisi atau tidak. Mikroskop ini juga digunakan untuk melihat ketebalan hasil pelapis.

\section{Pengamatan Struktur Mikro Menggunakan SEM (Scanning Electron Microscope)}

Setelah dilakukan pengujian korosi, permukaan sampel akan diamati selanjutnya. Pengamatan ini bertujuan untuk melihat ada atau tidaknya perubahan struktur mikro ataupun lapisan yang terbentuk. Alat yang digunakan untuk pengamatan yaitu SEM (Scanning Electron Microscope) adalah pemeriksaan struktur mikro yang lebih besar hingga 5.000 kali dibanding mikroskop optik seperti Gambar 3.4 dibawah ini:

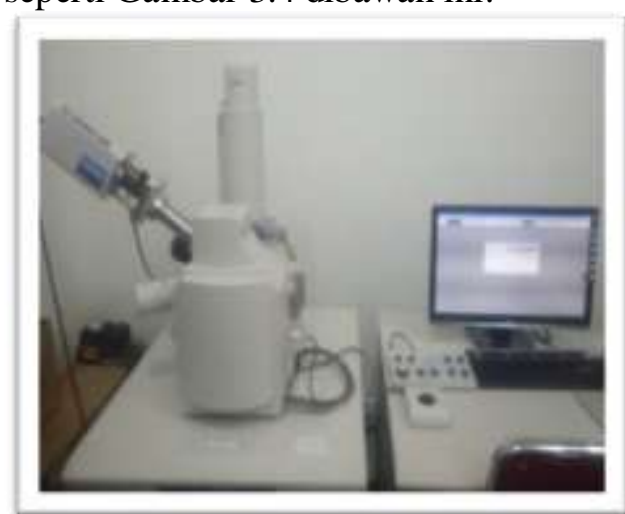

Gambar SEM (Scanning Electron Microscope)
Pengukuran Ketebalan CPTi yang Terlapisi HA (Thickness Gauge series GM 280)

Pengukuran ketebalan benda uji yang dicoating dapat diukur dengan Thickness Gauge series GM 280, dikhususkan untuk mengukur ketebalan permukaan dan mengukur lapisan pada objek yang telah dilapisi. Thickness Gauge series GM 280 bisa dilihat pada Gambar berikut:

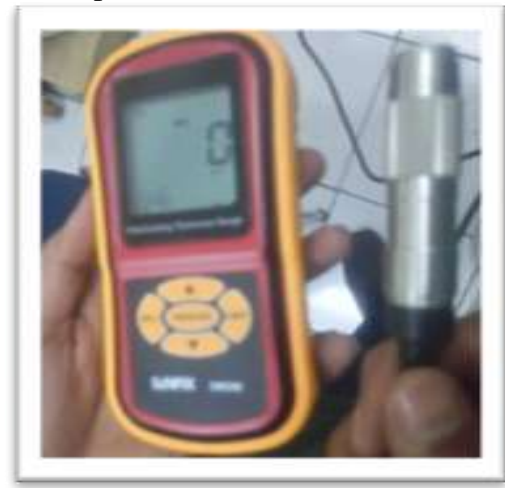

Gambar Thickness Gauge series GM 280

\section{HASIL DAN PEMBAHASAN}

Tebal lapisan permukaan CPTi yang terlapisi HA setelah disintering bisa dilihat pada sebagai berikut:

Tebal lapisan $(\mu \mathrm{m})$ CPTi dengan HA

\begin{tabular}{|c|c|c|}
\hline NO & waktu & Tebal Lapisan $(\boldsymbol{\mu m})$ \\
\hline 1 & 5 & 24,8 \\
\hline 2 & 10 & 28,5 \\
\hline 3 & 15 & 28,9 \\
\hline 4 & 20 & 30 \\
\hline 5 & 25 & 30,2 \\
\hline 6 & 30 & 32 \\
\hline 7 & 35 & 32,7 \\
\hline \multicolumn{2}{|c|}{ Pada diatas terlihat bahwa lapisan HA } \\
\hline
\end{tabular}

pada CPTi dengan variasi waktu nampak kenaikan tebal lapisannya ini bisa digambarkan pada Gambar 4.5 grafik ketebalan lapisan sebagai berikut: 


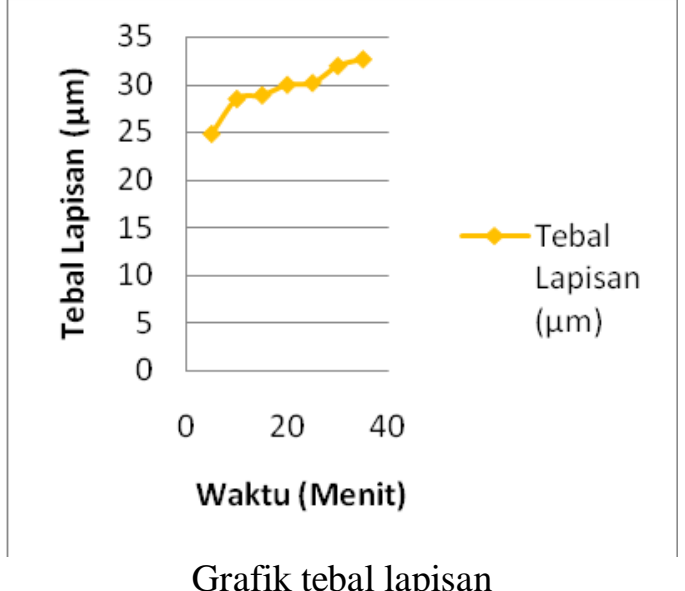

Grafik membuktikan semakin lama waktu pelapisan benda uji CPTi semakin tebal lapisan HA yang didapatkan. Tebal pelapisan HA ini bisa diukur dengan menggunakan alat ukur Thickness Gauge series GM 280.

Morfologi Permukaan Lapisan Setelah Proses EPD

Pengamatan lapisan hydroxyapatite yang terbentuk setelah proses pelapisan menggunakan metode Electrophoretic Deposition pada permukaan CPTi dapat dilihat pada Gambar :

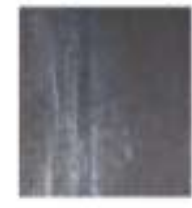

(a)

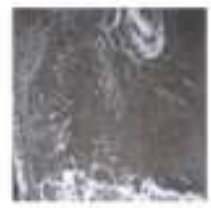

(e)

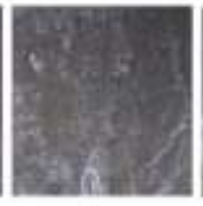

(b)

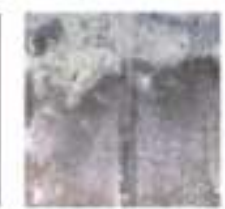

(6)

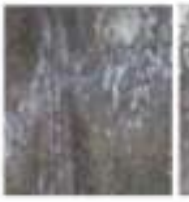

(c)

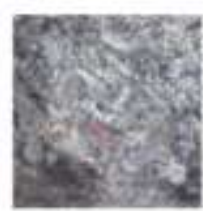

waktu 10 menit serbuk HA yang menempel tidak menutupi seluruh permukaan titanium murni, dan lapisan yang terbentuk tipis dan agak bergumpal. Hal ini juga berlaku pada benda uji kedua. Untuk benda uji waktu 25 menit untuk benda uji kelima lapisan yang terbentuk makin tebal menutupi seluruh permukaan, sedangkan pada benda uji terakhir benda uji 35 menit terlapisi dengan baik semua permukaannya untuk kerataan lapisan terlihat belum merata.

\section{SIMPULAN DAN SARAN}

Berdasarkan hasil penelitian yang dilakukan, didapatkan beberapa kesimpulan sebagai berikut:

1. Pada pengaturan waktu 10 menit, optimum pelapisan terjadi pada variasi 40 volt, sedangkan untuk waktu 35 menit optimum pelapisan pada 40 volt lapisan CPTi menebal.

2. Waktu dan voltase mempengaruhi ketebalan lapisan, semakin lama waktu proses dan peningkatan voltase maka ketebalan lapisan pun akan bertambah

\section{UCAPAN TERIMA KASIH}

Terimakasih kepada YISP yang sudah memberikan izin dan suport moril kepada peneliti dalam menyelesaikan pendidikan. Dan penulis juga mengucakap terimakasih kepada Bapak sekolah SMK Semen Padang yang sudah memeberikan izin kepada penulis untuk lanjut study S2, serta kepada seluruh teman-teman yang sudah membantu penulis dalam penulisan penelitian ini.

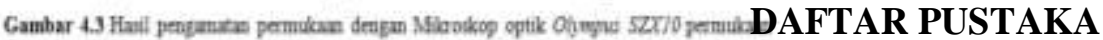

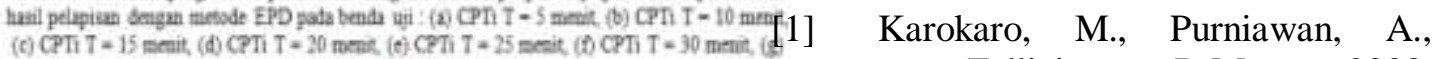
cri $T=35$ ment

diatas memperlihatkan hasil pengamatan permukaan lapisan dengan menggunakan mikroskop optik Olympus SZX10 dengan perbesaran 2 kali. Bagian yang berwarna hitam merupakan CPTi dan bagian yang putih merupakan hydroxiapatite yang terlapis pada permukaan CPTi.

Benda uji pertama yaitu variasi waktu 5 menit dengan Volt 40 dimana pada varisi benda uji ini tidak banyak terlihat HA yang menempel pada CPTi, ini dikarenakan waktu yang diberikan terlalu rendah. Pada benda uji
Fellicia, D.M., 2008, "Karakterisasi Lapisan Pasif Korosi Impant Commersial Pure Titanium Grade 2 Dengan Variasi Kekasaran Permukaan Pada Cairan Tubuh Buatan", Jurnal Ilmiah Sains dan Teknologi Vol. 7 No. 2, 97-105.

[2] Spenser Nicholas D, Texor Marcus, 1998, "Surface Modification, Surface Analysis and 
Biomaterials", Material

Science, ETH-Zurich

[3] Bombac D, Brojan, M, Krkovic, M., Turk, R., Zalar, A., 2001, "Characterization of Titanium and Stainless Steel Medical Implants Surfaces". Materials and Geoenvironment Vol. 54, 151-164.

[4] The International Programme on Chemical Safety (IPCS). Titanium. Geneva: World Health Organization. 1982; p. 14-49.

[5] Donachie, Matthew J, Jr. (1988). TITANIUM: $\quad$ A Technical Guide. Metals Park, OH: ASM International. p. 11

[6] Titanium" The Columbia Electronic Encyclopedia, 6th ed. Diakses 31 Oktober 2015

[7] Chamberlain J., Trethewey KR. 1991, KOROSI (Untuk Mahasiswa dan Rekayasawan), PT Gramedia Pustaka Utama, Jakarta.

[8] Campbell, F.C. Manufacturing Technology for Aerospace Structural Materials (edisi ke-1st). Elsevier. (2006).

[9] Dahlan, K., Prasetyanti, F., \& Sari,Y.W. (2009). "Sintesis hidroksiapatit dari cangkang telur menggunakan dry metode". Jurnal Biofisika 5(2): 71-78

[10] Hench, L.L., 1991, Bioceramics: From Concept to Clinic, Journal of American Ceramic Society, p. 1487-1510.

[11] Hydroxyapatite Coatings Prepared by A High Power Laminar Plasma Jet.. Diakses tanggal 11 Februari 2016 pukul 16.45 WIB.

http://web.unair.ac.id/admin/f ile/f 41130 korosi.pdf. 